Jörg Jewanski ${ }^{1}$, Sean A. Day², Julia Simner ${ }^{3}$, and Jamie Ward ${ }^{4}$

\author{
${ }^{1}$ Department Musikhochschule, University Münster, Germany \\ ${ }^{2}$ Department of English \& Journalism, Department of Behavioral and Social Sciences, \\ Trident Technical College, Charleston, South Carolina, US \\ ${ }^{3}$ Department of Psychology, University of Edinburgh, UK \\ ${ }^{4}$ Department of Psychology, University of Sussex, UK \\ Address correspondence to: \\ Dr. Jörg Jewanski, Breite Gasse 1. D-48143 Münster \\ Jewanski@gmx.de
}

\title{
The beginnings of an interdisciplinary study of synaesthesia: \\ Discussions about the Nussbaumer brothers (1873)
}

\begin{abstract}
In the context of synaesthesia research, the discussion about the Nussbaumer brothers today is totally forgotten. Two articles were published by one of these brothers in 1873 with self-observations about their synaesthesia and a 19-section questionnaire - the first questionnaire in the history of this phenomenon. What was new about their synaesthesia? How was it received? In which interdisciplinary contexts was synaesthesia placed? Which new theories were developed via the Nussbaumer discussion? We answer these questions and also resolve for the first time the true identity of F. A. Nussbaumer.
\end{abstract}

Keywords: self-observation; questionnaires; Müller's law of the specific energy of senses; Georg T.L. Sachs; coloured hearing; phonopsie; synaesthesia causation. 


\section{Introduction}

Why study synaesthesia? There are few fields in science which can boast of such a broad range of sub-disciplines as synaesthesia, given its wide range of manifestations (e.g., hearing colours, tasting shapes, feeling words). Hence, for researchers interested in interdisciplinarity, synaesthesia is a perfect subject. However, to study it, we need to ask which direction to follow. The case of the Nussbaumer brothers in 1873 may illustrate this not only perfectly but for the very first time in history, because cases and theories about synaesthesia before this time did not involve the interaction of so many different disciplines. The Nussbaumer brothers were both synaesthetes, and one wrote about their condition in two related articles $(1873 \mathrm{a} / \mathrm{c})$. Reviewers of Nussbaumer's self-observations did not know where to place this phenomenon. The first paper was published between articles about ovariotomy and cholera. Later we find reviews inside a journal for physicians in practice, but also in a journal for medical sciences. Did the phenomenon belong to pathology and relate to issues in the therapeutics of otology, or to Tinnitus Aurium? Could it be included in discussions of physiology? Or should it be relegated to merely an unclassified ailment? Was it at all connected with the ear, or with the eye (as a discussion in the 1850s suggested)? In this latter case, it would belong to ophthalmology. Or perhaps better still to otorhinolaryngology? Was it a disease that needed treatment? Perhaps by a surgeon, with aural specialisms? Or did synaesthesia belong to biology or even physics? If it was a disease, did it belong to the physiology of the senses or to physiological acoustics? Or even to evolution, if not to philosophy? Should we in 1873 reject synaesthesia, because it was such a very rare phenomenon, or should we include it in handbooks? For all of these questions, we find sources during the 1870s in context with discussion of the Nussbaumer brothers. And one further issue was raised: How did synaesthesia relate to the arts? One of the brothers himself drew a connection to art, and their synaesthesia dealt with musical tones. Our paper will demonstrate how the Nussbaumer brothers showed contemporary researchers that there were more than two ways to skin a cat.

\section{Nussbaumer's first article}

Our story begins in 1873, 4th of January, Saturday, Vienna, Austria, when the first of what would become three parts of an article was published 
in the weekly Wiener Medizinische Wochenschrift (Vienna medical weekly paper), signed in the name of J. A. Nussbaumer: Ueber subjektive >Farben empfindungen, die durch objektive ,Gehör empfindungen erzeugtwerden. Eine Mittheilung durch Beobachtungen an sich selbst (About subjective colour sensations, which are aroused from objective sound sensations. A paper based on observations of himself). During the next two weeks, the entire article was published (1873a).

In this article, J. A. Nussbaumer, whom we can now name Fidelis (see below), reported on his own childhood and that of his brother Johann, when Fidelis was five years old, and his brother Johann seven. They played a game using bells and other objects that would make a sound - like spoons or forks-which were all lined up attached along a string. Both brothers named the sounds with their colours, and each brother argued when their colours conflicted. Their parents did not understand and laughed at their game. Eighteen years later, in 1872, Nussbaumer corresponded with his brother, who lived as a clock maker in Vicenza, Italy. The younger brother had developed a questionnaire of 19 questions (1873a, col. 29-30) and sent it to him. Both brothers answered the questions independently from each other. The answers of the older brother were sent in a sealed letter, dated May9, 1872; Fidelis' own answers were written before his brother opened the questionnaire. Both letters were given to Prof. Brühl, whom we shall return to later. Eight questions, which are No. 2-9 of his questionnaire, deal with colours for single musical tones. Fidelis asked ten more questions, summarized here (with Johann's answers in parentheses, followed by Fidelis):

No. 1: Do you have sensations of colours while hearing a tone, and if so, since when?

(yes, since my youth / yes, since I was five years old)

No. 10: Listening to a chord do you have the sensation of only one colour or a compound of colours?

(the colours that accompany the tones melt from dark to bright and the reverse / a very vivid changing compound of colours where sometimes single colours appear stronger than others)

No. 11: If you have answered No. 10 with 'one colour', do you find this colour also in another single tone?

(question 10 was answered with a 'compound of colours '/ question 10 was answered with a 'compound of colours')

No. 12: If you answered No. 10 with 'compound of colours', can you distinguish the separate colours? 
(no / yes, the single colours can be distinguished, but I need to pay special attention)

No. 13: Do you have colour sensations when listening to a car trundling over cobbles?

(not clear to answer, I could compare it with dark grey or grey with dark yellow / I have colour sensations: grey, in most cases fading away with yellow, both colours are not always dark; fast driving light cars show the sensation of bright colours, slow driving heavy cars of dark grey)

No. 14: When striking a tone on a piano, bell and so on, do you hear only this specific tone or several tones?

(only one tone / up to eleven overtones)

No. 15: Which colour is a bright-sounding table tinker-bell?

(I can't name a particular colour, sometimes it is violet with bright blue, sometimes bluish yellow as in a bluish twinkling star/ not all sound the same way, most of them look yellowish upon striking and bluish upon fading away)

No. 16: Do you experience all colours connected with musical tones or are some colours missing?

(not all colours / not all colours)

No. 17: Which colours are the most frequent, which are rare?

(blue and yellow - brown and violet / frequent are blue, yellow and brown, the former is the most frequent, violet is very rare)

No. 18: Which colours can't be found attached to musical tones?

(red, green, pure black, pure white / red, pure black, pure white)

No. 19: Which colour is the high sound of a trumpet?

(the colour of flesh / transparent golden-yellow shining)

Nussbaumer's questionnaire on synaesthesia was the first in history. Many others were to follow: Fechner (developed in 1879; now lost, see Steinbrügge1887), Galton (developed in ca. 1879, see Burbridge 1984), Claparède and Flournoy (1892), Gruber (1893), Calkins (1895), LaignelLavastine (1901), Dresslar (1903), Anschütz (156 questions developed in 1925, published, for example, in Anschütz 1929: 19-24). In addition to his questionnaire, Nussbaumer gives more details about synaesthesia, some of which appear for the first time in history: he experiences synaesthesia even when dreaming; his synaesthesia is neither pleasant nor unpleasant; he can effectively get rid of his synaesthesia with full concentration on something different; the sensation is inside his head (it starts at the temple as a band 
of colours, which go to the middle of the forehead); the colours experienced by him and his brother are different in some ways, but similar in others. Johann added one interesting detail: "I don't know if it makes sense, but I will say this: If I were a painter and musician, then I could make colours exactly for each different tone, and find musical tones for each colour, including all possible dissonances; and people would then adjudge that we are gifted by Nature to find and present the relationship between light and sound" (1873a, col. 31). This is the first time in history that a connection between synaesthesia and art was described.

A central question for Nussbaumer about his sensations was their relation to Johannes Müller's law of the specific energy of senses (1826). This doctrine stated that each sensory organ is linked with its own separate nerve centre in the brain: the eye can only see, but not hear, the ear can only hear, but not see. Nussbaumer regarded his case as an affirmation of this axiom: "While simply a superficial view of this set of experiences from the 'specific energy of the sensory nerves' might be understood as contradictory, all observations allow themselves, under more detailed scrutiny, to easily fall back to their real conditions. Namely of simultaneous, direct stimulation of several respectively different perception-mediating sensory nerves by means of 'one' stimulation, or indirect stimulation of different sensory nerves as a consequence of the transfer of excitation of directly stimulated sensory nerves to other perception-mediating nerve fibers lying close by" (1873a, col. 5).

\section{Coloured hearing up to 1873}

Nussbaumer's observations were only the second time in history that a coloured hearing was described, and the first time in history that it was described in detail. The first synaesthete with this special condition was Georg Tobias Ludwig Sachs, a multi-synaesthete, who had given detailed examples of his colour synaesthesia for letters of the alphabet, tones of the musical scale, numbers, and days of the week (1812; cf. Jewanski, Day, and Ward 2009 and 2012). Sachs explained his coloured hearing in only two sentences. However, to understand this, we need first to be able to read the original Latin ${ }^{1}$, and then interpret his colours in reference to his own

\footnotetext{
"In scala musica voces a literis, quibus insignitae sunt, colores petunt eosdemque etiam hemitoniis ab iis derivatis communicant. Quamvis autem literae $g$ et $b$ coloris vestigium
} 
(minimal) musical knowledge. In fact, Sachs' examples per se encompassed only two notes: $g$ [in Latin nomenclature] - green(uncertain) and $b$ [in Latin nomenclature] - ash grey. However, because he tells us that "the tones in the musical scale depend on the letter with which they are designated", we have to take a look at Sachs' alphabet colours. In this, he gives colour examples for the letters A-E - I - O - U -Ue (ü) $-\mathrm{C}-\mathrm{D}-\mathrm{F}-\mathrm{H}-\mathrm{K}-\mathrm{M}-\mathrm{N}-$ $\mathrm{S}-\mathrm{W}$. Sachs also gives other clues about how his synaesthesia interprets musical notes; he writes: "The tones in the musical scale depend on the letter with which they are designated, and these relate also to the half-tones, which derive from them. Although the letters $g$ and $b$ flat actually do not carry a colour trace, nevertheless the fifth tone $(g)$ is recognized as green (uncertain) and the first accidental ( $b$ flat) is seen quite clearly by the ash grey colour."'Given this, we can now compare Sachs's coloured hearing with the one of the Nussbaumer brothers.

\begin{tabular}{|c|l|c|c|}
\hline & \multicolumn{1}{|c|}{$\begin{array}{c}\text { Georg Tobias Ludwig } \\
\text { Sachs (1812) }\end{array}$} & $\begin{array}{c}\text { Fidelis Alois Nussbaumer } \\
(1872)\end{array}$ & Johann Nussbaumer (1872) \\
\hline c & pale-ash-coloured & $\begin{array}{c}\text { C'”': upon striking, an } \\
\text { indeterminate whitish } \\
\text { colour mixture; } \\
\text { upon fading away, } \\
\text { transparent bright } \\
\text { bluish }\end{array}$ & $\begin{array}{c}\text { C'”': whitish yellow with } \\
\text { a breath of bright pink }\end{array}$ \\
\hline d & yellow & $\begin{array}{c}\text { D: chestnut brown with } \\
\text { individual brighter } \\
\text { stripes }\end{array}$ & $\begin{array}{c}\text { D: a mixing of dark blue and } \\
\text { brownish violet }\end{array}$ \\
\hline
\end{tabular}

fere nullum ostendant, tamen vox quinta (g) viridi (incerto) et diesis primaria (b) cinereo colore satis conspicua est." ( $(160$, pp. 82-83)

2 Not all letters have colours; different letters like I, M and $\mathrm{N}$ have the same colour white; the letters $G$ and $B$ are missing. For non-musicians, as Sachs was, the C-Major-scale mostly is the one which is regarded as the basic of music. Sachs himself wrote "nevertheless the fifth tone $(g)$ ", so his musical basic was a $C$ or rather the C-Major-scale. The question remains, what he means with the $b$. In the Latin version, Sachs writes "dieses primaria (b)", in the German translation, which was published by Julius Heinrich Gottlieb Schlegel in 1824 we read »der erste viertel Ton (b)« (p. 101), which can be translated literally as "the first quarter tone (b)". But the original term >dieses $<$ has a double meaning: first, an accidental (a sharp or a flat), second, the enharmonic comma. The later means the very small difference between the interval inside the overtone row and the intervals used inside our tempered tone system. The $b$ [in Latin and German nomenclature, but a $b$ flat in English] is the first note - it is No. 7 - inside the overtone row which sounds a little bit lower than written. But there is no reason why Sachs should mention this difference (and not the note itself) when listing his colours of a musical scale. So probably the »dieses primaria (b)« has to be translated as "the first accidental (b flat)". 


\begin{tabular}{|c|c|c|c|}
\hline e & $\begin{array}{l}\text { vermilion, more inclined } \\
\text { to rose }\end{array}$ & $\begin{array}{l}\text { e: dark leather, pigskin } \\
\text { yellow upon striking; } \\
\text { upon fading away, } \\
\text { (somewhat corn- } \\
\text { flower-) blue }\end{array}$ & $\begin{array}{l}\text { e: blue, but somewhat darker } \\
\text { than that of the tone } a\end{array}$ \\
\hline$f$ & dark grey & $\begin{array}{l}\text { f": transparent lemon } \\
\text { yellow } \\
\text { F: an indeterminate dark } \\
\text { grey, resulting from the } \\
\text { fact that alternating } \\
\text { somewhat brighter } \\
\text { and darker grey lines } \\
\text { are laid out on a dark } \\
\text { chestnut brown } \\
\text { background }\end{array}$ & $\begin{array}{l}\text { f': yellow, brighter than the } \\
\text { yellow from a' } \\
\text { F: black-violet }\end{array}$ \\
\hline$g$ & green (uncertain) & $\begin{array}{l}\text { g": upon striking, lemon } \\
\text { yellow; upon fading } \\
\text { away, bluish }\end{array}$ & g": lemon yellow \\
\hline a & $\begin{array}{l}\text { vermilion, however } \\
\text { more cinnabar }\end{array}$ & $\begin{array}{l}\text { a': upon striking, distinctly } \\
\text { bright bitter orange } \\
\text { yellow; it changes } \\
\text { colour in the course } \\
\text { of the tone until } \\
\text { indeterminate between } \\
\text { yellow and blue; finally } \\
\text { fades away as corn- } \\
\text { flower blue. } \\
\text { a: dark chamois yellow }\end{array}$ & $\begin{array}{l}\text { a': yellow, somewhat brighter } \\
\text { than ochre yellow } \\
\text { a: dark Prussian blue }\end{array}$ \\
\hline b flat & ash-grey & - & - \\
\hline$b$ & bluish ash-coloured & - & - \\
\hline
\end{tabular}

Sachs only gave the name of the musical tones without naming the octave transposition. So we do not know if the colour of the $d$, which is yellow, changes its shade being transposed several octaves higher or lower to a $D$ " (three octaves deeper) or a $d$ "' (three octaves higher). Sachs named the letters of the alphabet with capital letters and the names of the notes with small letters. We included the letters of the alphabet, which belong to a C-Major-scale, to our chart, integrating them in the 'normal' middle range $c-b$ [which is $c-h$ in Latin or German nomenclature] which is named the 'small octave'. In contrast, Fidelis Nussbaumer distinguished between different octave transpositions and did not consider all seven names of notes. So both systems are difficult to compare. In Sachs's synaesthesia, we cannot find a progression from dark to bright colours analogous to $c$ to $b$ (low to high tones). In the Nussbaumer brothers' synaesthesia, both have 
this progression from dark to bright (in colours) analogous to low and high (in tones: $D$ to $c^{\prime \prime \prime ') ~(c o m p a r e ~ o u r ~ c h a r t ~ i n ~ J e w a n s k i ~ e t ~ a l . ~ 2011: ~ 296) . ~ T h i s ~}$ progression comprises different colours even if the name of the tone does not change, but only the octave transposition: For Fidelis, $F$ is dark grey, but $f$ " transparent lemon yellow: for Johann, $F$ black-violet, but $f$ " yellow. So the brightness of a colour is superordinated to its name and depends on the octave progression of the tone. It is strange that this principle was not recognized by Nussbaumer's reviewers during the 1870s. If we compare the synaesthesia of both brothers, we find out that there are similarities because of the same underlying principle of darkness-brightness. Inside this system, some analogies are identical, some are a little different. It would have been interesting in 1873 to compare Sachs's and Nussbaumer's synaesthesia, but by that time Sachs had already been forgotten.

\section{The Nussbaumer - Brühl connection}

Who was J. A. Nussbaumer? Up until the current article, the identity of Nussbaumer had not been established. He was born as Fidelis Alois Nußbaumer (Nussbaumer) on March 23, 1848, in Klausen, today the Italian part of Tyrol, 100kilometres south of Innsbruck. (His name is misspelled in the title of the first part of his first article [1873a], but corrected in the second part, and printed with correct spelling in his second article [1873c]). Fidelis's father was Josef Nussbaumer, a commune administrator. In 1868, Fidelis passed his school leaving examination in Innsbruck and began to study natural sciences at the University of Innsbruck, but did so for only three semesters. In 1870, he switched to the University of Vienna, which he left in 1873 without a degree. In 1872, he became second president of the recently founded Akademischer Verein der Naturhistoriker an der Wiener Universität (Academic Society of Natural Historians at the University of Vienna), and in 1876 its president for several years (Rogenhofer 1877: 4-8; Vieltorf and Nussbaumer 1876). This society was a loose fusion of interesting individuals, mostly students, who occasionally met for exchanges and lectures. In 1873, Nussbaumer published two articles about his synaesthesia (1873a/b), which also were published as a booklet in the same year $(1873 \mathrm{c} / \mathrm{d})$; the first one was reprinted, again in the same year, in a medical journal (1873e). In 1874, he published an article about physical connections between tones and colours (1874a), also reprinted as a booklet (1874b; compare "[Reviewer]" 1874; Plath 1875: 8-10; and Mahling 1923:66-70), probably to find some type of context for his synaesthesia. From 1872 to 1877, Nussbaumer was the 
editor of papers (Berichte und wissenschaftliche Mittheilungen / reports and scientific papers) from his society. In 1887, we know he was still alive when the otologist Hermann Steinbrügge, in context with his inaugural speech (about synaesthesia) as a professor of medicine, contacted him (Steinbrügge 1887: 8-9; compare Körner1901).

Nussbaumer knew that his coloured hearing was a new scientific phenomenon - by his time, the two sentences written by Sachs had been forgotten -and he, Nussbaumer, was not a famous scientist, but just a 24-yearold student. Nussbaumer had to consider the possibility that no-one would believe him, and that no-one would print his article. In this situation, he made a clever move. He sought the support of a famous scientist and found this target in a certain Prof. Brühl. Brühl wrote a letter of reference for Nussbaumer signed 'end of December 1872', about the scientific qualities of Nussbaumer and his serious approach to studies. Brühl also attested to the colour sensations of Nussbaumer, which he estimated by the fact that, although Nussbaumer had no musical abilities or perfect pitch, he could nonetheless name the musical tones because they always appeared with a distinctive colour. So Brühl was sure that Nussbaumer could perceive two sensations via one sensory input. Nussbaumer printed this letter of reference in a footnote in his article, and this allowed Nussbaumer to shield himself behind a famous scientist.

Nussbaumer referred to 'Prof. Brühl' without a first name, because the article was published in a Vienna medical journal where Brühl was already known. Today, in 2013, we must find out, who exactly Brühl was (for biography and writings compare Eisenberg 1893: 60-65; Pagel 1901: 262; "Bruehl" 1929; "Brühl” 1957). Carl (Karl) Bernhard Brühl (Bruehl) was born in 1820 in Prague, in today's Czech Republic. From 1861 to 1890, he was professor of zootomy at the University of Vienna, where in 1863 he became the founder and director (up to 1890) of the institute of zootomy. During this tenure, Brühl got into contact with Nussbaumer - in 1871. Brühl's scientific output was enormous: more than one hundred publications, mainly about osteology. Beside this, between 1871 and 1890, Brühl became a well-known scientist in Vienna and, every Sunday, he began to give public lectures Ueber den Körperbau des Menschen und der Tiere (About physique of human beings and animals) and Uebermenschliche Anatomie und Physiologie (About human anatomy and physiology) - these were the same lectures Nussbaumer visited in 1871. Between 1851 and 1874, Brühl published many articles in the Wiener Medizinische Wochenschrift (Vienna medical weekly 
paper), an important medical journal, and he helped Nussbaumer to publish his article in the same journal. Brühl died in 1899 in Graz, Austria.

\section{Nussbaumer's second article and the comments by Benedikt and Hock}

One outcome of Nussbaumer's article was that he was invited to give a lecture about it at a meeting of the Aerztlicher Verein in Wien (Society of Physicians in Vienna), which had a fortnightly journal of their own, in which his lecture was announced on February $24^{\text {th }}$ ("Programm" 1873), only five weeks after his series of articles in the Wiener Medizinische Wochenschrift. Two days later, his lecture took place on February $26^{\text {th }}$. Two weeks after that, his lecture - somewhat different in style and content to his first article - was printed in the Mittheilungen des Aerztlichen Vereins in Wien (Reports of the Society of Physicians in Vienna) on March $10^{\text {th }}$ (1873c).

Nussbaumer knew that his audience were physicians, for whom the content of his lecture was totally new and who probably would regard him as an interesting 'patient' and his colour sensation as a new disease. He was not aware of the history of synaesthesia, but only some years earlier an anonymous Italian reviewer had reported dramatically: "This [synaesthesia] would be a new disease coming from France, and it seems to constitute a new illness of the eyes, or at least the visual sense" ("[Reviewer]" 1864: 387). Nussbaumer was introduced as a "stud. philos." ("Programm" 1873), so he was only a student without reputation which he desperately would want for his topic. So Nussbaumer had to be careful: he started out by explaining the incredibility of his surroundings, afterwards he read Brühl's whole letter of reference. Being prepared for attacks in this way, he presented the results of his questionnaire and was very careful in phrasing his explanations:

What concerns me, if I would be inclined to search for the cause of such a double perception in the central organ, and would like to accept that the visual impressions and hearing impressions of the sensing brain portions stand in a certain leading connection certainly an acceptance which explains just as little when it can be proven, and seems already to speak against the fact - is that, for me, tone perception can impart colours, but not also the reverse, colour perceptions imparting tones (pp. 59-60). 
In Italy in the same year 1873, the physiologist Filippo Lussana described what he considered to be the anatomical closeness of regions in the brain specialized for colour, music and language (Lussana 1873: 122; cf. Jewanski et al. 2011: 300-301). This would support, independently from Nussbaumer, the possibility of a key connection between brain regions. At the end of Nussbaumer's lecture, there was a discussion and two comments were printed as an appendix to his article. The first was by 'Prof. Benedikt' (for biography and writings, compare Pagel 1901: 130-132; Benedikt 1906; "Benedikt" 1929; "Benedikt" 1935; "Benedikt" 1957; "Benedikt" 1996; "Benedikt"2002). Moritz Benedikt was born in 1835 in Eisenstadt, Austria, and had, since 1869, been professor of electrotherapy and pathology of nerves at the University of Vienna, and since 1874, director of the neurological department of the polyclinic in Vienna. He generated more than one hundred publications and died in Vienna in 1920. In 1873, when he commented upon Nussbaumer's lecture, Benedikt was a professor of the pathology of nerves, and his comment went in this direction. He declared the phenomenon, which is "an interesting patient history" (1873: 60), not as a physiological, but as a pathological one, because it is not observed otherwise. Benedikt was sure that, after Nussbaumer's excellent introspection, more cases would be discovered, as had happened when he himself sometime before had first described 'Platzschwindel' (agoraphobia). As it happened, there were not many new cases of synaesthesia following Nussbaumer's article; this really took hold in the 1880 s after the large empirical study by Bleuler and Lehmann (1881). Benedikt argued that, since Nussbaumer's brother also "suffers" (p. 61) from similar sensations, a hereditary predisposition should be considered. He also requested that Nussbaumer stop his self-observations, lest the phenomena should overpower him. Although Benedikt regarded Nussbaumer's perception as pathological, which does not reflect today's thinking, he was right in suggesting that this sensation was hereditary. Benedikt proposed the idea of a heterotopy although this could not be confirmed.

Because Benedikt did not publish on synaesthesia, his oral comment to Nussbaumer's lecture is the only statement by him on this topic, and he is also mentioned in some of the reviews of Nussbaumer's articles, as we will see later. During the 1880s and 1890s, his comment was often reproduced or added to bibliographies; for example: Bleuler/Lehmann (1881: 2-3), Steinbrügge (1887: 8), Suarez de Mendoza (1890: 162, only in the bibliography), Millet (1892: 23), Krohn (1892: 39, only in the bibliography), or Clavière (1898: 175 , only in the bibliography). Via this reception, Benedikt became a kind 
of 'synaesthesia researcher', and this was probably one of the reasons why he was chosen to be part of a committee to analyse the phenomenon. This took place during the Congrès international de psychologie physiologie, held in Paris in 1889. During a section on Audition colorée (this term was chosen to denote what we today name synaesthesia) on August 8, a discussion took place, in which Benedikt again spoke about Nussbaumer, now in slightly less harsh terms:

\begin{abstract}
I have advised this student whose brother shows the same phenomena to not give himself over to these experiments, unless he wants to sacrifice his sanity. It's difficult in these cases to draw the exact boundary between psychology and pathology. The trigeminal nerve plays an important role here; there are very immediate connections with all the senses. I would advise not doing too many experiments on these subjects, because the experiments themselves might not be dangerous. The key concern is turning them into hypochondriacs, because they believe that there is something extraordinary in their brains that might lead to madness. It's for that reason that I told this particular student straight away to no longer continue in these experiments, if he didn't want to sacrifice himself for science (Benedikt 1890).
\end{abstract}

It must have been a strange situation for Benedikt, sixteen years after declaring Nussbaumer's observations as pathological, now being part of a committee to analyse synaesthesia, not as an interesting patient history, but in a psychological-physiological context. And eight years before, an empirical study had been published by Bleuler and Lehmann (1881), where Benedikt was criticized for his "not applying" and "depressing advice" to Nussbaumer, because they had shown from 76 synaesthetes that such people "in no case" have to be "psychopathic" (p. 3).

The other comment that followed Nussbaumer's lecture was given by a 'Dr. Hock' (for biography and writings, compare Pagel 1901:754; Wernich 1931; "Hock" 1959). Jakob Hock was born in 1831 in Prague, in today's Czech Republic, and studied at the University of Vienna, where he worked from 1866 on as an ophthalmologist. In 1872, he became an associate professor at the University of Vienna, was a co-founder of the Wiener Allgemeine Poliklinik (Vienna Public Polyclinic) and in 1882 he founded an institute of ophthalmology. Hock published more than 50 studies about ophthalmology and died in 1890 in Vienna. In February 1873, he also was the main editor of the journal Mittheilungen des Aerztlichen Vereins in Wien 
(Papers of the Medical Society in Vienna) ("Programm" 1873), in which Nussbaumer's article was printed. Hock was more open minded than Benedikt, and warned about those not believing this phenomenon or trying to explain it with a facile catch phrase such as 'hysteria' or 'hypochondria', which did nothing to explain it. Hock encouraged physiologists and acousticians to pay attention to this phenomenon. He also did something very simple, and we ask ourselves why no other medical doctor had done likewise, such as Cornaz (1851), Perroud (1863), or Chabalier (1864), who had all three published on synaesthesia previously. Hock analysed the eyes of the synaesthete, and from this concluded: "While sounding the tuning fork, I could not, under such conditions, perceive the slightest change. Hence no perceptible change takes place at the retina and the optic nerves during the distinctly specified colour perception" (1873: 68).

It was a first in history that three famous scientists (Benedikt, Brühl, Hock) from different areas (neurology, osteology, ophthalmology) not only became familiar with synaesthesia, but actually commented upon it although they were not influenced to continue further in the study of the condition.

There were several other notable features of the Nussbaumer case. By being able to trace his synaesthesia back to the age of 5 years, Fidelis Nussbaumer became the youngest documented child case with synaesthesia during the $19^{\text {th }}$ century, although he reported on it only retrospectively as an adult. He was likely to have experienced synaesthesia even at the age of three or four years old, but we simply have no record about it. Unfortunately, Nussbaumer does not write if and how his synaesthesia may have changed since his childhood. The earliest children documented with synaesthesia during the $19^{\text {th }}$ century were Ellen Tucker Emerson (born 1839, source from 1848, when she was eight), followed by this case of Fidelis Nussbaumer (born 1848 , source from 1873, antedated to 1853 , when he was five). The third were school children in Boston (born ca. 1876, if we accept ca. one year between submitting and publishing a paper), source from 1883, when they were around six (Jewanski et al. 2013). Nussbaumer's observations were also notable for being the first in history describing two synaesthetes within one family, although he has to share this attribute with two brothers from the Tubachi family in Parma, Italy, with a voice to colour - synaesthesia, documented by Lussana (1873; cf. Jewanski et al. 2011: 299-301). 


\section{Nussbaumer's term 'Phonopsie'}

In an annotation to his article, Nussbaumer coined the term 'Phonopsie', derived from his special kind of synaesthesia, the later so-called 'coloured hearing'. He wrote: "Should it be desirable to give a shorter name to the phenomenon than I used for this paper [about subjective colour sensations, which are produced by objective sound sensations], I would like to apply the name 'Phonopsia' because of its brevity as well as because of the case that this name, for me, seems to describe best this sound seeing" (1873c: 60). It is not clear if Nussbaumerused his term to apply to the process of getting double sensations or for the outcome of that process, but it is likely he meant the process itself (see also Bleuler and Lehmann, 1881: 4).

Nussbaumer's term is the earliest German attempt to name the phenomenon; Sachs (1812: 80: $§ 157$ ) had written about "obscurare praesentatio" (dark ideas). In writings in German, we only find Cornaz's borrowed French term Hyperchromatopsie (1848: 150), translated as Chromatopseudopsie (Rau 1850: 115), respectively Chromatopseudopsia (Theile 1850: 384), but these terms were not in wide use. Because Nussbaumer was not aware of the history, he did not know that there were other kinds of synaesthesia different from his own, to which different names were given:'hyperchromatopsie', because of the perception of too many colours (Cornaz 1851); or 'pseudochromesthésie', because of the perception of false colours (Chabalier 1864). But all known cases of synaesthesia up to 1873 deal with synaesthesias triggering - specifically - colour. The only exception was the number form described for the first time in history by the American poet Hannah Reba Hudson (1873), but this was only linked to the synaesthesia literature some time later by Francis Galton (1880: 256). The terms chosen by Cornaz and Chabalier derived from the 'concurrent' or secondary sensation (i.e., colours), while Nussbaumer's term derived from the 'inducer' or primary sensation (i.e., sound).

It is strange that none of the reviewers mentioned Nussbaumer's new term. If we compare it with the reception of Cornaz's article (1851), we find that nearly everybody mentioned this latter's new term. The reason for this may be that the term only appeared in Nussbaumer's second article (1873c), while most of the reviewers referred to his first one (1873a), because this was published in an established journal, while his second 
article was published in a type of society's newsletter, which was difficult to obtain - even today ${ }^{3}$.

Bleuler and Lehmann (1881:3-4) used the terms Secundärempfindungen (secondary sensations), Secundärvorstellungen (secondary imaginations) and Doppelempfindungen (double sensations) for the condition we today name synaesthesia. If a synaesthete had an optical sensation, they named his concurrent Photisma. If this was aroused by an acoustic impulse they named it Schallphotisma (sound photisma). Analogically, they used the term Phonisma for the secondary sensation if a synaesthete had an acoustic primary sensation. Nussbaumer's term Phonopsie, if it refers to the outcome of his synaesthesia, would be comparable to their term Photisma; if it refers to the process, it would be comparable to their term Secundärempfindung. Although Nussbaumer was only aware of his own kind of sound-to-colour synaesthesia, Bleuler and Lehmann discovered many other kinds, so his term would have been too narrow for them. A second reason for them to refuse to take up Nussbaumer's term was that they may have regarded it as too predetermined.

Théodore Flournoy, in his large and influential book Des phénomènes de synopsie audition colorée. Photismes - schemes visuels - personnifications (1893), displaced Bleuler and Lehmann's terminology (and also Nussbaumer's) with the term Synopsie (Synopsia). Nussbaumer's own term was rediscovered in the title of the medical doctoral thesis of Friedrich Wehofer, 'Farbenhören' (chromatische Phonopsien) bei Musik (Colour hearing [chromatic phonopsiae] while listening to music) (1912), but did not become accepted. Nearly 40 years after Nussbaumer, Wehofer wrote a similar study. At that time, he was able to base his article on a long list of references (curiously without Sachs, although he did refer to Cornaz1851, and Suarez de Mendoza1890). Wehofer reviewed these sources, and afterwards

3 Some years later, Grützner (1888: 905) and even Mahling (1926: 279) declared that they were not able to get a copy, and even today the Mittheilungen are no longer located in Germany or Austria, but only in the United States, Chicago, Illinois, Center for Research Libraries, and in Boston, Massachusetts, Harvard University, Medical School Countway Library. Only the reprint of the second article as a booklet can be located today in Austria, in one library in Kremsmünster, Stift. But this booklet was not mentioned in the reviews. And even if the reviewer provided bibliographical dates for the second article, they are mostly not precise enough, especially for Hock's or Benedikt's comment, so you get the impression that the reviewers rather referred to other reviews than to the article itself. Perhaps they thought it might be a reprint of the first one. 
described his synaesthesia. It is strange to imagine that Nussbaumer, with an enlarged version of his article, was probably able to get a medical doctor degree in 1912. But, in 1873, his synaesthesia was regarded as a pathological individual case, and even Wehofer, at the end of his own thesis (p. 52), criticized Benedikt for the latter's verdict on Nussbaumer, which Wehofer, later, did not apply to himself.

\section{Nussbaumer's missing historical knowledge and the consequences of this}

Nussbaumer was not aware of the history of synaesthesia prior to 1873 . He was neither a physician, nor skilled in finding the few scientific references about synaesthesia, and so he did not mention other cases and theories (Jewanski et al. 2011). The audience of his lecture, including Benedikt and Hock, had to react spontaneously and very probably without any history as to this phenomenon. When Nussbaumer explained that he could not find references earlier than his own case, they believed him. Also, in the huge reception to his articles during the following years, this fact was again accepted by all of his reviewers, and this created the new 'fact' that Nussbaumer's case of joined sensations was the first of its kind in history. Even in the very influential book by Bleuler and Lehmann (1881), the history of synaesthesia began with Nussbaumer (p. 2) and reinforced this 'fact'. The only possible new case of synaesthesia mentioned by Nussbaumer and by him only - was of a Hungarian musician, who many years earlier had reported having a similar sensations himself. However, this person had since died and Nussbaumer had heard about it only in report (1873c: 59). So this was too vague to be included in the list of synaesthetes prior to 1873 (Jewanski 2013). One possible candidate for the Hungarian musician is Franz Liszt, who was often mentioned in the context of synaesthesia during the $19^{\text {th }}$ century. However, Liszt died in 1886, thirteen years after the publication of Nussbaumer's articles.

More than 20 years earlier, Cornaz had asked, and attempted to answer, several basic questions such as 'Is this state [of synaesthesia] found equally in men and women?', 'Is this state congenital? Is it always congenital? Can it disappear with age?', and 'Isn't it just a simple memory relationship' (Cornaz 1851; cf. Jewanski et al. 2012a, 2012b). Nussbaumer was not aware of this article, so could not build on it, but instead concentrated on a detailed self-description. But in contrast to Cornaz, Nussbaumer compared his 
observations with Müller's axiom and provided the first questionnaire in history. Unfortunately, Bleuler and Lehmann (1881) also were not aware of Cornaz's study, so Cornaz's ideas were temporarily consigned to oblivion and research on synaesthesia again started new with Nussbaumer. In any case, Nussbaumer's articles rather mirrored the self-observations of Sachs rather than the theoretical musings of Cornaz. In this respect, Nussbaumer's articles fall back to a pre-Cornaz time.

The research about synaesthesia before 1873 (above all, research by Sachs and Cornaz) was only rediscovered by the larger bibliographies written later, during the 1890s (Suarez de Mendoza 1890; Krohn 1892; Clavière 1898), prepared for by Féré (1887). Indeed, studies before 1872 (Kaiser) or 1873 (Nussbaumer) were absent even from the German-language research of Richard Hilbert in 1884, which had the very best bibliography in Germany up until this point (with 12 titles), and again from the medical dissertations of Ludwig Deichmann (1889) and Albert Ellinger (1889).

\section{The reception and influence of Nussbaumer's articles}

Until the end of the 1870s, Nussbaumer's articles were reviewed several times. One review is a complete reprint of his first article (1873a) in the weekly appearing Medizinische Neuigkeiten für praktische Ärzte (Medical news for physicians in practice) and with this came a high appreciation of its content (1873e). The editorial team accentuated that they would not print the article without Prof. Brühl's endorsement (p. 102). They went on to reprint the article in three parts (without Brühl's letter of recommendation and without a footnote by Nussbaumer about a woman who always saw the name 'Louise' in blue ${ }^{4}$ ) as the original print (with a little bit different apportionment), between March 20 and April12, only five weeks after Nussbaumer's lecture and only two and a half week after Nussbaumer's article in the Mittheilungen ${ }^{5}$.

4 Given this is limited to only one name, we can probably omit her from the list of synaesthetes before 1873 (Jewanski 2013).

5 The journal was published in Erlangen, Germany, by chance the same city, were Georg Sachs, in 1812, got his medical doctor degree with a study about albinism. This study is the proof of Sachs being the first documented case of synaesthesia in history. 
A detailed review by $\mathrm{H}$. Schöler was published on May $3^{\text {rd }}$, the same year in the German weekly Centralblatt für die medizinischen Wissenschaften (Central journal of the medical sciences). Here, as in the reprint, the authority of Brühl is accentuated. In his review, Schöler misspelled Nussbaumer's name as 'J. Nussbaum' and also declared 'the physiological, objective validity of this double sensation" as "not existing" (p. 315), in part because he had objections that would not be made today. For example, Schöler was suspicious of the fact that there were discrepancies in the colours experienced by both brothers, although today we know that there is indeed some degree of idiosyncrasy from synaesthete to synaesthete. In fact, almost all of Schöler points are simply what we know today to be varying characteristics of synaesthesia (e.g., that colours need not project into the visual field; that they might require concentration etc.). To some extent, Schöler's points of criticism represent a dissection of synaesthesia into its sub-features, which we can recognize today. For example, his comment on where colours are experienced relates to the known individual difference concerning whether colours are projected into space or seen in the mind's eye - today known as 'projector' versus 'associator' synaesthesia respectively. However, in 1873, these observations served simply as a reason to reject the phenomenon.

On June 28 the same year, a short anonymous review ("[Reviewer]" 1873) was published in the Literarisches Centralblatt für Deutschland (Literarily central journal for Germany), a highly recommended review journal for nearly all areas of science. Nussbaumer's booklet (1873b) was discussed in the section Philosophy, between a review about an aesthetic analysis of a poem by Goethe and an essay about sophistic rhetoric. As well as in Schöler's review, in the first sentence, the comparison with Müller's law is highlighted. Whereas Schöler regarded Nussbaumer's observations as a possible exceptional position, this later reviewer saw Nussbaumeras "contradicting the law in a direct way". The reviewer expressed a hope that more cases of this kind would be discovered and, if so, that these observations might "be able to give a different shape to the physiology of the sense organs".

On October $9^{\text {th }}, 1873$, Nussbaumer's first article (1873a) was reviewed in the United States, in the weekly Boston Medical and Surgical Journal, inside a Report of Otology, under the section Pathology and Therapeutics, by the medical doctor J. Orne Green (1873). It was printed next to reviews on studies about transformation of the mucous membrane, transection 
of the eardrum, cases illustrative of cerebral pathology, and a new method of operating for the cleft lobule of the ear. Green also started his review with a comparison to Müller's law, which, he claimed, Nussbaumer "attacks" (p. 356), followed by along description of Nussbaumer's observations. Although Green referred only to the tripartited article, he also mentioned in detail the ideas by Benedikt. It is unclear where Green got his information from. Nonetheless, this review was to have a huge influence because it was reprinted the following year (Green1874) by the aural surgeon Laurence Turnbull (1874) inside the Philadelphia Medical Times. This was an omnibus review of new research on Tinnitus aurium, a term describing the sensation of noise without acoustic stimulation. Turnbull did not go back to Nussbaumer's original articles, although in his review he cited from German books and journals. His omnibus review was again reprinted in 1879 by the aural surgeon C. E. Shoemaker in his book The Ear: its Diseases and Injuries and Their Treatment (Green 1879). Shoemaker did not include it in the section Physiology, but rather in Unclassified Ailments. Shoemaker lived in Reading, Pennsylvania, less than $100 \mathrm{~km}$ away from Philadelphia. This may be one reason why he was aware of the Philadelphia Medical Times. Two years earlier, another reception of Nussbaumer's articles took place within the United States, and again in Pennsylvania. Charles Henry Burnett summarized Nussbaumer's observations in his book The Ear: its Anatomy, Physiology, and Diseases. A Practical Treatise for the Use of Medical Students and Practitioners, in the chapter Diseases and Treatment / Examination of Patients (Burnett 1877: 196). Burnett provided different details than Green, so he probably went back to the original articles, although he may have come across Nussbaumer via Turnbull's article in the Philadelphia Medical Times, because he worked as an aural surgeon in Philadelphia. Burnett included the passage about Nussbaumer in the second revised edition of his book (1884: 189).

As for France, Nussbaumer's title of his article was translated into French and the bibliographical dates (1873a) were listed inside the Revue des sciences médicales en France et à l'étranger (»Ueber subjective Farbenempfindungen«, 1873). Three years later, Nussbaumer's article (1873a) was discussed by Nuël in the article Rétine (physiologique), in the huge Dictionnaire encyclopédique des sciences médicales, and led to a new theory about the origin of synaesthesia: "This involves a referral/transmission in the central nervous system, as is often seen for other sensory nerves" (p. 24). In 1882, again in an article Rétine, it is only mentioned within the references (Duval 1882: 395). One year later, in 1883, Jean Baratoux published the first 
of his several articles about synaesthesia in a journal for otorhinolaryngology, beginning with the "phénomene bizarre" of Nussbaumer (Baratoux 1883: $65)$.

In 1874, Victor Urbantschitsch summarized Nussbaumer's article (1873c) for the Medizinisch-chirurgische Rundschau (Medical surgery review). Between 1883 and 1908, Urbantschitsch published several studies about subjective sensations, influences of the senses, and synaesthesia (Mahling 1926: 283). This was the first time in history that a reviewer about a study on synaesthesia later went onto conduct his own research on this topic.

One year later, the philosopher Wilhelm Tobias regarded Nussbaumer's observations as not authentic and not a falsification of Müller's law, because they had not been checked in detail (1875: 117). In 1881, Alfred Goldschneider, in his medical doctoral dissertation about the doctrine of the specific energies of the sense organs, regarded Nussbaumer's sensations not as a falsification of Müller's law, but as an "enormous cultivated physiological ability" (p. 4), analogical to Nussbaumer's enormous ability to hear eleven overtones. In summary then, the question of Nussbaumer's theory was reacted to in a number of different ways: Nussbaumer himself supported the theory, Schöler had regarded it as "an exceptional position"; for the anonymous reviewer, it "seems to contradict the law in a direct way"; for Green, it "attacks the physiological axiom"; for Tobias, it can't refute the law, because the observations were not checked in detail; and, for Goldschneider, it was only an "enormous cultivated physiological ability". So sources can be found for every possible position one could have taken.

In $1874 / 75$, at least three reviews were published as part of omnibus reviews in Germany and Austria, where new research from 1873 was presented. Here, Nussbaumer's observations were integrated in medical or physical contexts: In the Jahresbericht über die Leistungen und Fortschritte in der gesammten Medicin (Year report of efforts and progress in the whole of medicine), a summary of Nussbaumer's article (1873a) was integrated in three sentences by Peter Ludvig Panum (1874) in the section Physiology of the senses, voice and speech. One of the three sentences was devoted to Brühl's endorsement. In the Jahresbericht über die Leistungen und Fortschritte im Gebiete der Ophthalmologie (Year report about the efforts and progress in ophthalmology), the editor of the report, Albrecht Nagel, a professor of ophthalmology, provided a long summary of Nussbaumer's 
article (1873a) with the assessment "strange" (Nagel 1875: 101). He also included sections of statements by Hock (which he included in the bibliography) and Brühl (which he did not include in the bibliography). He classified the article in the section Physiology of the Eye. In Die Fortschritte der Physik (Progresses in physics), Theodor Hoh, professor of physics, summarized Nussbaumer's article (1873a) in the section Physiological acoustics and added an observation of his own: In 1868, a blind person told him that he drew a parallel between the sound of musical instruments and colours: organ with violet, trumpet and trombone with red, flute and harp with blue, a high tuned string and a whistle with yellow (1878: 365). But Hoh did not write whether the colours were perceived, felt or imagined. So this information is probably too vague to add this blind person to the list of synaesthetes prior to 1873 (Jewanski 2013). In the Jahresberichte über die Fortschritte der Anatomie und Physiologie (Year reports about the progresses in anatomy and physiology), Nussbaumer's article is listed by Krüger (1875) in the section Physiologie of the eye, but is not discussed.

Outside of a medical or physical context, the Nussbaumer articles initiated new theories about the origin of the phenomenon. One was written by the German professor of physiology Johannes Ranke (1875) in the context of discussions about evolution, who suggested that the borders between the senses are not so clearly separated as generally believed. He argued that, in primitive animal organisms, a type of common feeling replaces the other sense sensations. Within a proceeding development, this common sense separates specific sense sensations one by one, beginning with the sense of touch. Ranke argued that our opinions about senses and the law of the specific energy of the senses only derive from adults. "But it seems to me, as we can still test on ourselves, that an absolute distinction between sensations does not exist, as the law of the specific energies of the senses, strictly executed, demands. Clearest to me, a certain connection can also still be seen by adults between the senses of touch and hearing. Everyone knows the peculiar sensation of very strong and deep tones in the ear, which more or less give the impression of mechanic kicks and vibrations; completely analogous, very high and shrill tones lead to a tickling and trilling sensation in the ear, which can be compared to tickling tactile sensations. Therefore the sensation of tones in their upper and lower bounds seem to switch into a tactile sensation; the clear distinction vanishes here" (p. 161). Here, Ranke referred to the Nussbaumer brothers, "children with red and yellow sensations of sound" (p. 162), who showed that there also are connections between the senses of hearing and seeing. Ranke based his knowledge about 
the Nussbaumer brothers on both of Fidelis Nussbaumer's articles (1873a/c), and on Schöler (1873), without overtaking Schöler's refusing opinion.

The philosopher George Henry Lewes discussed Nussbaumer's observations in his popular Problems of Life and Mind (1879) under the topic of Double Sensation. His whole chapter is based on Nussbaumer's observations (1873a), which Lewes interpreted as being related to other common phenomena such as: "setting the teeth on edge' by scratching glass" (p. 284; or "the familiar fact of an optical impression being accompanied by a revival of tactual and muscular feelings" (p. 286). Lewes concluded:

The organ of Sound is not only different from that of Colour, but the central terminations of the auditory and optic nerves (so far as any termination can be anatomically surmised) are wide apart. [...] A stimulus excites the auditory nerve and centre, the Sensorium responds in a sound. But if the response of sound is to replace the stimulation of the optic centre, it can only be in one of two ways: either there must be a path of communication between the two centres, so that the agitation of the one sets the other in action, or the Sensorium, in which both centres penetrate and lose themselves, giving up to it their energy, is alternately set in the attitude of sound and color, and this so rapidly that the two responses seem simultaneous (Lewes 1879: 285-286).

Because of his vivid and detailed descriptions, Nussbaumer's articles appeared in nearly every history of synaesthesia and made him the most widely known synaesthete of the $19^{\text {th }}$ century. As well as providing a number of 'first times in history', the primary contribution of Nussbaumer was perhaps to make synaesthesia, for the very first time, an interdisciplinary topic. While Cornaz helped synaesthesia to become a serious topic of research, Nussbaumer (and his reviewers) helped synaesthesia to become the focus of interest for a wide range of individuals, and this is perhaps today still one of its most fascinating aspects.

\section{References}

Anschütz, Georg 1929. Das Farbe-Ton-Problem im psychischen Gesamtbereich. Sonderphänomene komplexer optischer Synästhesien >Sichtgebilde`.Halle: Marhold. 
Baratoux, Jean 1883. "De l'audition colorée." Revue mensuelle de laryngologie, d'otologie et de rhinologie 4.3: 65-69.

Benedikt, Moritz. 1873. [Comment on Nussbaumer 1873a, 1873c]. In Nussbaumer (1873a, 60-61).

Benedikt, Moritz. 1890. [Contribution to a discussion, 1889]. In Congrès international de psychologie physiologie. Compte rendu présenté par la Société de psychologie physiologie de Paris, 95. Paris: Bureau des revues.

Benedikt, Moritz. 1906. Aus meinem Leben. Erinnerungen und Erörterungen. Wien: Carl Konegen.

Benedikt, Moritz. 1929. In Franz Hübotter (ed.). Biographisches Lexikon der hervorragenden Ärzte aller Zeiten und Völker, zweite Auflage, vol. 1, p. 69. Berlin-Wien: Urban \& Schwarzenberg.

Benedikt, Moritz. 1935. In Wilhelm Haberling \& H. Vierordt (eds.). Biographisches Lexikon der hervorragenden Ärzte aller Zeiten und Völker, zweite Auflage. Ergänzungsbandzuden Bänden I-V, 86. Berlin-Wien: Urban \& Schwarzenberg.

Benedikt, Moritz. 1957. In Leo Santifaller (ed.). Österreichisches biographisches Lexikon 1815-1950, vol. 1, p. 120. Graz-Köln: Hermann Böhlaus Nachfolger.

Benedikt, Moritz. 1996. In Alma Kreuter (ed.). Deutschsprachige Neurologen und Psychiater. Ein biographisch-bibliographisches Lexikon von den Vorläufern bis zur Mitte des 20. Jahrhunderts, vol. 1, pp. 87-93. München et al.: K. G. Saur.

Benedikt, Moritz. 2002. In Dietrich von Engelhardt(ed.). Biographische Enzyklopädie deutschsprachiger Mediziner, vol. 1, p. 43. München: K. G. Saur.

Bleuler, Eugen and KarlLehmann. 1881. Zwangsmässige Lichtempfindungen durch Schall und verwandte Erscheinungen auf dem Gebiete der andern Sinnesempfindungen. Leipzig: Fues.

Bruehl, Karl Bernhard. 1929. In F. Hübotter (ed.). Biographisches Lexikon der hervorragenden Ärzte aller Zeiten und Völker, zweite Auflage, vol. 1, p. 732. Berlin-Wien: Urban \& Schwarzenberg.

Brühl, Carl Bernhard. 1872. [Letter of reference.] In Nussbaumer (1873b, 4-5, annotation).

Brühl, Karl Bernhard. 1957. In L. Santifaller (ed.). Österreichisches biographisches Lexikon 1815-1950, vol. 1, p. 120. Graz-Köln: Hermann Böhlaus Nachfolger.

Burbridge, David. 1994. "An exploration of Francis Galton's imagery studies." The British Journal for the History of Science 27.4: 443-463.

Burnett, Charles. H. 1877. The ear: its anatomy, physiology, and diseases; a practical treatise for the use of medical students and practitioners. Philadelphia, Pennsylvania: Henry C. Lea.

Burnett, Charles H. 1884. The ear: its anatomy, physiology, and diseases; a practical treatise for the use of medical students and practitioners, Second Edition, Revised and Rewritten. Philadelphia, Pennsylvania: Henry C. Lea's Son \& Co. Calkins, Mary Whiton. 1895. "Synæsthesia." The American Journal of Psychology 71: 90-107. 
Chabalier. 1864. "De la pseudochromesthésie." Journal de médicine de Lyon 1.2: 92-102.

Claparède, Édouard and Théodore Flournoy. 1892. "Enquête sur l'audition colorée." Archives des sciences physiques et naturelles 28: 505-508.

Clavière, J. 1898. "L'audition colorée." L'Année psychologique 5.1: 161-178.

Cornaz, Charles-Auguste-Édouard. 1848. Des abnormités congéniales des yeux et de leurs annexes. Lausanne: Georges Bridel.

Cornaz, Charles-Auguste-Édouard. 1851. "De L'Hyperchromatopsie." Annales D'Oculistique 25/5/1 (1-3): 3-9.

Cytowic, Richard. 1989. Synesthesia: A Union of the Senses. New York: Springer.

Day, Sean A. 2013, April 6. Demographic aspects of synesthesia. Retrieved from http://www.daysyn.com/Types-of-Syn.html.

Deichmann, Ludwig. 1889. Erregung secundärer Empfindungen im Gebiete der Sinnesorgane. Greifswald: Julius Abel.

Dresslar, F. B.1893. "Are chromæsthesias variable? A study of an individual case." The American Journal of Psychology 14.3-4: 368-382.

Duval, M. 1882. Rétine. In Jaccoud (ed.). Nouveau dictionnaire de médecine et de chirurgie pratiques, vol. 31, 318-397. Paris: J.-B. Baillière.

Eisenberg, Ludwig. 1893. Das geistige Wien.Künstler- und Schriftsteller-Lexikon, vol. 2. Wien: Daberkow.

Ellinger, Albert 1889. Über Doppelempfindung (Secundärempfindung). Stuttgart: W. Kohlhammer.

Féré, Ch. 1887. "La visión colorée et l'équivalence des excitations sensorielles." Comptes rendus des séances de la société debiologie et de ses filiales 8/4(39): 791-795.

Flournoy, Théodore. 1893. Des phénomènes de synopsie audition colorée. Photismes-schemes visuels-personnifications. Paris: Alcan.

Galton, Francis. 1880. "Visualised numerals." Nature 21: 252-256.

Goldschneider, A. 1881. Die Lehre von den specifischen Energien der Sinnesorgane. Berlin: L. Schumacher.

Green, J. Orne 1873. [Review of Nussbaumer 1873a]. The Boston Medical and Surgical Journal 89.15 [October 9]: 356-357 [reprint: Turnbull 1874].

Green, J. O. 1874. [Reprint of Green 1873]. In L. Turnbull, “On Tinnitus aurium”; Philadelphia Medical Times. A Weekly Journal of Medical and Surgical Science 4.39 [June27]: 610-611.

Green, J. 1879. [Reprint of Green 1874]. In C. E. Shoemaker (ed.). The ear: its diseases and injuries and their treatment, 296-297. Reading, Philadelphia: B. F. Owen.

Gruber, Éduard 1893. "Questionnaire psychologique sur l'audition colorée, figurée et illuminée." Revue philosophique de la France 18.35: 499-502.

Grützner, P. 1888. "Ueber den Einfluss einer Sinneserregung auf die übrigen Sinnesempfindungen." Deutsche medicinische Wochenschrift 14.44: 905-907. 
Hilbert, Richard 1884. "Ueber Association von Geschmacks- und Geruchsempfindungen mit Farben und Association von Klängen mit Formvorstellungen.” Klinische Blätter für Augenheilkunde 22: 1-4.

Hock, Jakob.1873. "Ophthalmoskopische Untersuchung der Augen des Herrn Nussbaumer.“ In Nussbaumer (1873c, 62-63).

Hock, Jakob. 1959. In L. Santifaller (ed.). Österreichisches biographisches Lexikon 1815-1950, vol. 2, 346-347. Graz-Köln: Hermann Böhlaus Nachfolger.

Hock, Jakob. 2002. In D. von Engelhardt (ed.). Biographische Enzyklopädie deutschsprachiger Mediziner, vol. 1, p. 287. München: K. G. Saur.

Hoh, T. 1878. [Review on Nussbaumer 1873a]. Die Fortschritte der Physik im Jahre 1873, vol. 29, pp. 363-365. Berlin: G. Reimer.

Hudson, Hannah Reba. 1873. "Idiosyncrasies." The Atlantic Monthly 31.184: 197201.

Jewanski, Jörg. 2013. Synaesthesia in the nineteenth century: Scientific origins. In Julia Simner and Edward M. Hubbard (eds.). The Oxford Handbook of Synesthesia. Oxford: Oxford University Press.

Jewanski, Jörg, Sean A. Day, and Jamie Ward. 2009. “A colorful albino: The first documented case of synaesthesia, reported by Georg Tobias Ludwig Sachs in 1812." Journal of the History of the Neurosciences 18: 293-303. doi: 10.1080/09647040802431946 [with English translation of the relevant passages; enlarged version: Jewanski, Day and Ward 2012a].

Jewanski, Jörg, Sean A. Day and Jamie Ward. 2012. "1812: el año en que por primera vez se habla de Sinestesia.” In Maria José de Córdoba and Dina Riccò (eds.), Sinestesia: Las fundamentos teóricos, artísticos y cientificos, 40-72. Granada: Fundacion Internacional Artecittà [with German, Latin, English and Spanish version of the relevant passages; short version: Jewanski, Day and Ward 2009].

Jewanski, Jörg, Julia Simner, Sean A. Day and Jamie Ward. 2011. "The development of a scientific understanding of synaesthesia from early case studies 18491873." Journal of the History of the Neurosciences 20: 284-305. doi: 10.1080/0964704X.2010.528240.

Jewanski, Jörg, Julia Simner, Sean A. Day and Jamie Ward. 2012. “Édouard Cornaz (1825-1911) and his importance as founder of synaesthesia research." Musik-, Tanz- und Kunsttherapie. Zeitschrift für künstlerische Therapien 24, [in print; reworked version from Jewanski et al. 2012c].

Jewanski, Jörg, Julia Simner, Sean A. Day and Jamie Ward. 2012b. The first researcher on synaesthesia: Édouard Cornaz (1825-1911). In Maria José de Córdoba (ed.). Actas IV Congreso Internacional de Sinestesia: Ciencia y Arte (Alméria, 16 al 19 Febrero 2012). Granada: Fundación Internacional Artecittà (CD-ROM) [reworked: Jewanski et al. 2012b].

Jewanski, Jörg, Julia Simner, Sean A. Day and Jamie Ward. 2013. The beginning of research on synaesthesia with children. Searching for traces in the $19^{\text {th }}$ century. In Christine Söffing and Jasmin Sinha (eds.). Synaesthesia with children. Creativity and learning, Conference proceedings (Ulm, 11/12 May 2012). Luxemburg [in print]. 
Kaiser, Heinrich 1872. Compendium der physiologischen Optik (p. 197). Wiesbaden: C. W. Kreidel's Verlag.

Körner, O. 1901. “Obituary. Hermann Steinbrügge.” Archives of Otology 30: 554.

Krüger, F. 1875. [Reference of Nussbaumer 1873a]. In F. Hofmann and G. Schwalbe (eds.), Jahresberichte über die Fortschritte der Anatomie und Physiologie, vol. 2, Literatur 1873, 502. Leipzig: F. C. W. Vogel.

Laignel-Lavastine. 1901. "Audition colorée familiale." Revue neurologique 9.23: 1152-1162.

Lewes, George Henry. 1879. Problems of Life and Mind (Third Series). London: Trübner \& Co.

Lussana, Filippo 1873. Fisiologia dei colori. Padone: F. Sacchetto.

Mahling, Friedrich. 1923. Die Geschichte des Problems wechselseitiger Beziehungen zwischen Ton und Farbe. Berlin: Unpublished Dissertation.

Mahling Friedrich. 1926. "Das Problem der 'Audition colorée'. Eine historischkritische Untersuchung." Archiv für die gesamte Psychologie 57: 165-301.

Müller, Johannes, Peter 1826. Zur vergleichenden Physiologie des Gesichtssinnes des Menschen und der Thiere nebst einem Versuch ueber die Bewegungen der Augen und des menschlichen Blickes. Leipzig: C. Cnobloch.

Nuël. 1876. Rétine (physiologie). In A. Dechambre (ed.). Dictionnaire encyclopédie des sciences médicales, série 3, tome 4, Ret - Rhu, 22-101. Paris: G. Masson \& P. Asselin.

Nussbaumer, Fidelis Alois. 1873a. "Ueber subjektive 'Farben'empfindungen, die durch objektive 'Gehör'empfindungen erzeugt werden. Eine Mittheilung durch Beobachtungen an sich selbst." Wiener Medizinische Wochenschrift 1 [January-4]; 4-7; 2 [January-11]: 28-31; 3 [January-18]: 52-54. [Including Brühl 1872; identical with Nussbaumer $1873 \mathrm{~b}$ and 1873e.]

Nussbaumer, Fidelis Alois. 1873b. Ueber subjektive 'Farben'empfindungen, die durch objektive 'Gehör'empfindungen erzeugt werden. Eine Mittheilung durch Beobachtungen an sich selbst. Wien: Selbstverlag. [Identical with Nussbaumer 1873a and 1873e.]

Nussbaumer, Fidelis Alois. 1873c. "Ueber subjective Farben-Empfindungen, welche durch objective Gehör-Empfindungen erzeugt werden." Mittheilungen des Aerztlichen Vereines in Wien 2.5 [March-10]: 49-63. [Including Brühl 1872, Benedikt 1873, and Hock 1873; identical with Nussbaumer 1873d.]

Nussbaumer, Fidelis Alois. 1873d. Ueber subjective Farben-Empfindungen, welche durch objective Gehör-Empfindungen erzeugt werden. Wien: Finsterbeck. [Identical with Nussbaumer 1873c.]

Nussbaumer, Fidelis Alois. 1873e. "Ueber subjektive Farbenempfindungen, die durch objektive Gehörempfindungen erzeugt werden." Medizinische Neuigkeiten für praktische Ärzte 23.13 [March-29]: 102-104; 23.14 [April-5]: 108-110, 23.15 [April-12]: 114-116. [Identical with Nussbaumer 1873a/b, but excluding Brühl 1872.] 
Nussbaumer, Fidelis Alois. 1874a. "Ton und Farbe.” Wissenschaftliche Mittheilungen aus dem Akademischen Vereine der Naturhistoriker in Wien 2: 3-38 [identical with Nussbauer 1874b.]

Nussbaumer, Fidelis Alois. 1874b. Ton und Farbe. Wien: Erste Wiener VereinsBuchdruckerei [identical with Nussbaumer 1874a].

Pagel, Julius (ed.). 1901. Biographisches Lexikon hervorragender Ärzte des neunzehnten Jahrhunderts. Mit einer historischen Einleitung. Berlin-Wien: Urban \& Schwarzenberg.

Panum, Peter, Ludvig 1874. [Review of Nussbaumer 1873a]. In Rudolf Virchow and August Hirsch (eds.). Jahresbericht über die Leistungen und Fortschritte in der gesammten Medicin. Bericht für das Jahr 1873, vol. 7 (col. 183). Berlin: August Hirschwald.

Perroud 1863. "De 1'hyperchromatopsie." Mémoires et compte-rendus de la société des sciences médicales de Lyon 2: 37-41.

Plath, Julius 1875. Uber die Versuche einer Farbenharmonielehre nach akustischen Prinzipien. In Programm der Klosterschule Witzleben, einer Stiftung der Familie von Witzleben, 1-16. Halle: Waisenhaus.

"Programm der Sitzung des Aerztlichen Vereines, Mittwoch den 26. Februar 1873, 7 Uhr Abends." Mittheilungen des Aerztlichen Vereines in Wien 2.4: 48.

Rau. 1850. [Review of Cornaz 1848]. Schweizerische Zeitschrift für Medizin, Chirurgie und Geburtshülfe, 114-115.

[Reviewer]. 1864. [Review of A. Berti (1865), "Della pseudocromestesia", Archivo Italiano per la malatie nervose e più particolarmente per le alienazioni mentali (Milano), 2:22-28]. Atti dell' Istituto Veneto di Scienze, Lettere ed Arti 10.3: 386-388.

[Reviewer]. 1873. [Review of Nussbaumer 1873b]. Literarisches Centralblatt für Deutschland 25: col. 803.

[Reviewer]. 1874. [Review of Nussbaumer 1874b]. Literarisches Centralblatt für Deutschland 51: col. 1701.

Rogenhofer, Alais 1907. Geschichte des Naturwissenschaftlichen Vereins an der Universität Wien. In Festschrift des Naturwissenschaftlichen Vereins an der Universität Wien, 3-20. Wien: Verlag des Naturwissenschaftlichen Vereins.

Sachs, Georg Tobias Ludwig 1812. Historiae naturalis duorum leucaetiopum: Auctoris ipsius et sororis eius. Erlangen.

Schlegel, Julius H. G. 1824. Ein Beitrag zur nähern Kenntniß der Albinos. Meiningen: Keyßnersche Hofbuchhandlung.

Schöler, H. 1873. [Review of Nussbaumer 1873a/c]. Centralblatt für die medicinischen Wissenschaften, 20 [May-3]: 313-315.

Steinbrügge, Herman 1887. Über secundäre Sinnes-empfindungen. Wiesbaden: Johan Fridrich Bergmann.

Suarez de Mendoza, Ferdinand. 1890. L'Audition colorée. Étude sur les fausses sensations secondaires physiologiques et particulièrement sur les pseudosensations de couleurs associées aux perceptions objectives des sons. Paris: Octave Doin. 
Theile. 1850. [Review of Cornaz 1848]. In H. E. Richter, \& A. Winter (eds.). Carl Christian Schmidt's Jahrbücher der in- und ausländischen gesammten Medicin, vol. 66,383-384. Leizpig: Otto Wigand.

Tobias, Wilhelm. 1875. Grenzen der Philosophie. Berlin: G. W. F. Müller.

"Ueber subjective Farbenempfindungen." 1873. [Reference on Nussbaumer 1873a incl. the titles translated]. Revue des sciences médicales en France et à l'étranger 1.2: 958.

Urbantschitsch, Viktor 1874. [Review of Nussbaumer 1873c]. Medizinischchirurgische Rundschau. Zeitschrift für die gesamte praktische Heilkunde 15 / N.S., 5: 66-67.

Vieltorf, H. and Fidelis Alois Nussbaumer. 1877. [Deputation text, April 8, 1876]. Verhandlungen der kaiserlich-königlichen zoologisch-botanischen Gesellschaft in Wien 26: 42.

Wehofer, F. 1912. “'Farbenhören' (chromatische Phonopsien) bei Musik. Ein Beitrag zur Psychologie der Synästhesien auf Grund eigener Beobachtungen.” Zeitschrift für angewandte Psychologie und psychologische Sammelforschung 7.1: 1-54.

Wernich 1931. Hock, Jakob. In Wilhelm Haberling, Franz Hübotter and Hermann Vierordt (eds.), Biographisches Lexikon der hervorragenden Ärzte aller Zeiten und Völker, zweite Auflage, vol. 3, 244-245. Berlin-Wien: Urban \& Schwarzenberg.

This article began as a paper presented at the Annual Conference of the $U K$ Synaesthesia Association in Brighton, University of Sussex in March 2010 and was first sketched as a chapter inside an article (Jewanski et al., 2011, pp. 295-299). All translations from German, French, Latin, and Italian into English are done by the authors. A special thanks for biographical information about Nussbaumer to several persons in Austria: Mag. Martin Georg Enne, Vienna University Archive, Dr. Peter Goller, Innsbruck University Archive, Mag. Dr. Johannes Seidl, MAS, Vienna University Archive, Mag. Matthias Svojtka, University Vienna, Faculty of Biodiversity. 